\title{
Penyakit Hemolitik pada Bayi Baru Lahir
}

\author{
Martina Rentauli Sihombing, Dominica Pita Sari
}

\author{
Staf Pengajar Bagian Patologi Klinik \\ Fakultas Kedokteran Universitas Kristen Krida Wacana \\ Alamat Korespondensi: dominica.sari@ukrida.ac.id
}

\begin{abstract}
Abstrak
Penyakit hemolitik pada bayi baru lahir adalah sindrom anemia hemolitik dan ikterus yang terjadi akibat destruksi eritrosit yang sudah dilapisi oleh antibodi. Patofisiologi pada penyakit ini adalah karena adanya proses imun yang dimulai saat terjadi sensitisasi pada kehamilan pertama saat darah janin yang memasuki sirkulasi ibu. Adanya ketidakcocokan golongan darah atau rhesus tersebut memicu proses imun ibu membentuk antibodi sehingga menyebabkan penghancuran eritrosit bayi. Hal ini dapat disebabkan oleh adanya ketidakcocokan golongan darah $\mathrm{ABO}$, rhesus, atau golongan darah lainnya. Perbedaan golongan darah antara ibu dan bayi terjadi saat ada faktor golongan darah janin yang diwariskan dari ayahnya tidak dimiliki oleh ibu. Gejala yang timbul antara lain hiperbilirubinemia, anemia, hepatosplenomegali, dan lainnya. Pemeriksaan laboratorium yang berfungsi sebagai pemeriksaan penyaring adalah: Uji Rossete, uji Kleihauer-Betke (KB), flowsitometri dan tes antiglobulin indirek. Pemeriksaan rutin lainnya adalah pemeriksaan darah rutin, kadar bilirubin, golongan darah dan rhesus. Penatalaksanaan saat kehamilan dapat berupa transfusi intrauterin atau imunomodulasi, sementara penatalaksanaan paska kelahiran dapat dengan transfusi tukar, fototerapi atau pemberian imunoglobulin
\end{abstract}

Kata kunci : Penyakit hemolitik pada bayi baru lahir, sensitisasi, antibodi, imunoglobulin

\section{Hemolytic Disease of The Newborn}

\begin{abstract}
Hemolytic Disease of the Newborn is a syndrome of hemolytic anemia and jaundice due to the destruction of erythrocytes. This condition is due to the blood type incompatibility of the mother and the baby, such as incompatibility of ABO blood groups, rhesus, or other blood groups. During the first pregnancy, when fetal blood enters the maternal circulation, sensitization occurs triggering an immune process. Antibodies are formed and coat erythrocytes, causing destruction of the baby's erythrocytes. The difference in blood type between mother and baby occurs when there is a factor of fetal blood type inherited from his father that not owned by the mother. Symptoms that arise include hyperbilirubinemia, anemia, hepatosplenomegaly, and others. Laboratory screening tests are conducted by Rossete test, Kleihauer-Betke test (KB), flowcytometry and indirect antiglobulin test. Other routine tests are routine blood tests, bilirubin levels, blood type and rhesus tests. Management during pregnancy can be either by intrauterine transfusion or immunomodulation, while postnatal management can consits of exchange transfusions, phototherapy or immunoglobulin administration.
\end{abstract}

Keywords: Hemolytic Disease of the Newborn, sensitization, antibodies, immunoglobuline 


\section{Pendahuluan}

Hemolytic Disease of the Newborn (HDN), adalah sindrom anemia hemolitik dan ikterus yang terjadi akibat destruksi eritrosit yang sudah dilapisi oleh antibodi tersensitisasi pada bayi. HDN juga dikenal juga dengan eritroblastosis fetalis. HDN diperkirakan terjadi 3-80 kasus per 100.000 kelahiran per tahun di Amerika Serikat. ${ }^{1,2}$

Ibu membentuk antibodi akibat perdarahan transplasental terhadap sel-sel janin yang inkompatibel. Antibodi ini tidak berbahaya bagi sel ibu, tetapi menembus plasenta untuk masuk ke dalam sirkulasi janin dan menyerang antigen yang ada di eritrosit janin., ${ }^{1,3}$

Eritroblastosis fetalis ditemukan tahun 1609 saat wanita Perancis melahirkan bayi kembar dengan salah satu bayi edema dan meninggal saat dilahirkan, dan bayi lainnya mengalami ikterus dan meninggal beberapa hari kemudian. Pada tahun 1950-an setelah ditemukan penyebab utama kematian adalah akibat diserangnya eritrosit bayi akibat adanya antibodi dari ibu yang dibentuk akibat ketidakcocokan golongan darah ibu dan janin selama di dalam rahim maka dimulai pencegahan melalui antenatal care yang mengurangi mortalitas. ${ }^{2,3}$

\section{Etiologi}

Hemolytic Disease of the Newborn (HDN) disebabkan oleh adanya perdarahan fetomaternal dengan ketidakcocokan golongan darah antara ibu dan bayi yang memicu proses imun untuk penghancuran eritrosit bayi dan menimbulkan gejala bervariasi hingga timbul komplikasi. Perbedaan golongan darah antara ibu dan bayi terjadi saat ada faktor golongan darah janin yang diwariskan dari ayahnya tidak dimiliki oleh ibu. ${ }^{1,3}$

Pertahanan tubuh bayi pada saat baru dilahirkan hanya sistem imun primer dan dibantu oleh adanya antibodi ibu. Selama kehamilan ada antibodi ibu yang melewati plasenta dan memasuki sirkulasi janin. Antibodi ibu ini menjadikan eritrosit janin sebagai target untuk dihancurkan bila sebelumnya sudah tersensitisasi. ${ }^{1,3}$

\section{Klasifikasi : ${ }^{4}$}

a. HDN akibat ketidakcocokan rhesus (Rh): merupakan kasus yang paling sering ditemukan dan umumnya lebih parah dibandingkan dengan jenis golongan darah lain. Antibodi terhadap rhesus yang dapat menyebabkan ketidakcocokan adalah anti $-\mathrm{c}$, anti-E, anti-C, anti-e dan terutama anti-D yang paling sering menyebabkan HDN berat.

b. Hemolytic Disease of the Newborn (HDN) akibat ketidakcocokan golongan darah ABO: terjadi sekitar 3\% dari semua kasus HDN. Ibu memiliki golongan darah $\mathrm{O}$ sedangkan bayi bergolongan darah $\mathrm{A}$ atau B. HDN akibat ketidakcocokan golongan darah $\mathrm{ABO}$ biasanya tidak separah inkompatibilitas rhesus namun dapat lebih sering dan lebih parah pada neonatus Afrika-Amerika.

c. Hemolytic Disease of the Newborn (HDN) akibat ketidakcocokan golongan darah lainnya: merupakan kasus HDN yang paling jarang terjadi (sekitar 0,5\%). Antibodi yang terbentuk dapat dari golongan darah Kell, Kidd, Duffy atau MNS.

\section{Patofisiologi}

Proses imun pada HDN dimulai saat terjadi sensitisasi pada kehamilan pertama saat darah janin yang memasuki sirkulasi ibu. Inkompatibilitas rhesus umumnya saat persalinan terjadi perdarahan transplasenta anak pertama dengan $\mathrm{Rh}-\mathrm{D}$ positif pada ibu dengan Rh-D negatif, yang lebih sering pada komplikasi persalinan atau kala memanjang. Sensitisasi juga dapat terjadi saat dilakukan prosedur klinik seperti terminasi kehamilan, amniosentesis, kordosentesis atau saat pengambilan sampel villi chorialis. Adanya ketidakcocokan golongan darah memicu ibu membentuk antibodi. ${ }^{3-5,7}$

Risiko sensitisasi terhadap antigen Rh-D akan berkurang bila bayi ada ketidakcocokan golongan darah ABO. Setiap sel bayi yang lolos ke dalam sirkulasi ibu akan dihancurkan cepat oleh anti-A atau anti-B sehingga mengurangi kemungkinan terpaparnya antigen Rh-D. ${ }^{4,8}$

Awalnya anti-D ibu yang terbentuk pada saat tersensitisasi adalah Imunoglobulin (Ig) M yang tidak dapat melalui plasenta. Stimulasi 
produksi IgG secara cepat akan terjadi pada terdeteksi lagi (Gambar 1). IgG dapat melalui plasenta dan memasuki sirkulasi bayi untuk berikatan dengan Rh-D pada eritrosit bayi dan dihancurkan (hemolisis). ${ }^{3-6,8}$

Kecepatan penghancuran eritrosit menentukan tingkat keparahan HDN menjadi ringan, sedang atau berat. HDN ringan terjadi hemolisis dalam jumlah kecil yang masih dapat ditoleransi oleh bayi dan menjadi anemia ringan saat dilahirkan.,

Hemolisis dalam jumlah yang besar akan meningkatkan bilirubin sebagai produk pemecahan, namun kadar bilirubin dalam darah bayi akan tetap rendah selama kehamilan karena kemampuan plasenta untuk mengangkut bilirubin dari sirkulasi janin.

Setelah 24 jam pasca dilahirkan, kadar bilirubin akan sangat cepat meningkat karena kehamilan berikutnya saat antigen Rh-D hepar bayi belum matur dan tidak mampu memetabolisme bilirubin yang menumpuk. Bilirubin dapat masuk ke dalam otak (kernikterus) bila kadar tetap meningkat dan bersifat toksik terhadap sel-sel saraf sehinggga menimbulkan komplikasi kerusakan saraf permanen bila bayi tetap hidup. ${ }^{4,6,8}$

Hemolisis yang terjadi sangat cepat dan lama akan menyebabkan anemia berat pada bayi. Hepar, limpa dan organ lain mengkompensasi kebutuhan dengan cara meningkatkan produksi eritrosit. Hal ini mengakibatkan hepatospleno-megali sampai gagal hati. Eritrosit imatur (eritroblast) akan dikeluarkan ke sirkulasi sehingga disebut sebagai eritroblastosis fetalis. ${ }^{3,4,8}$

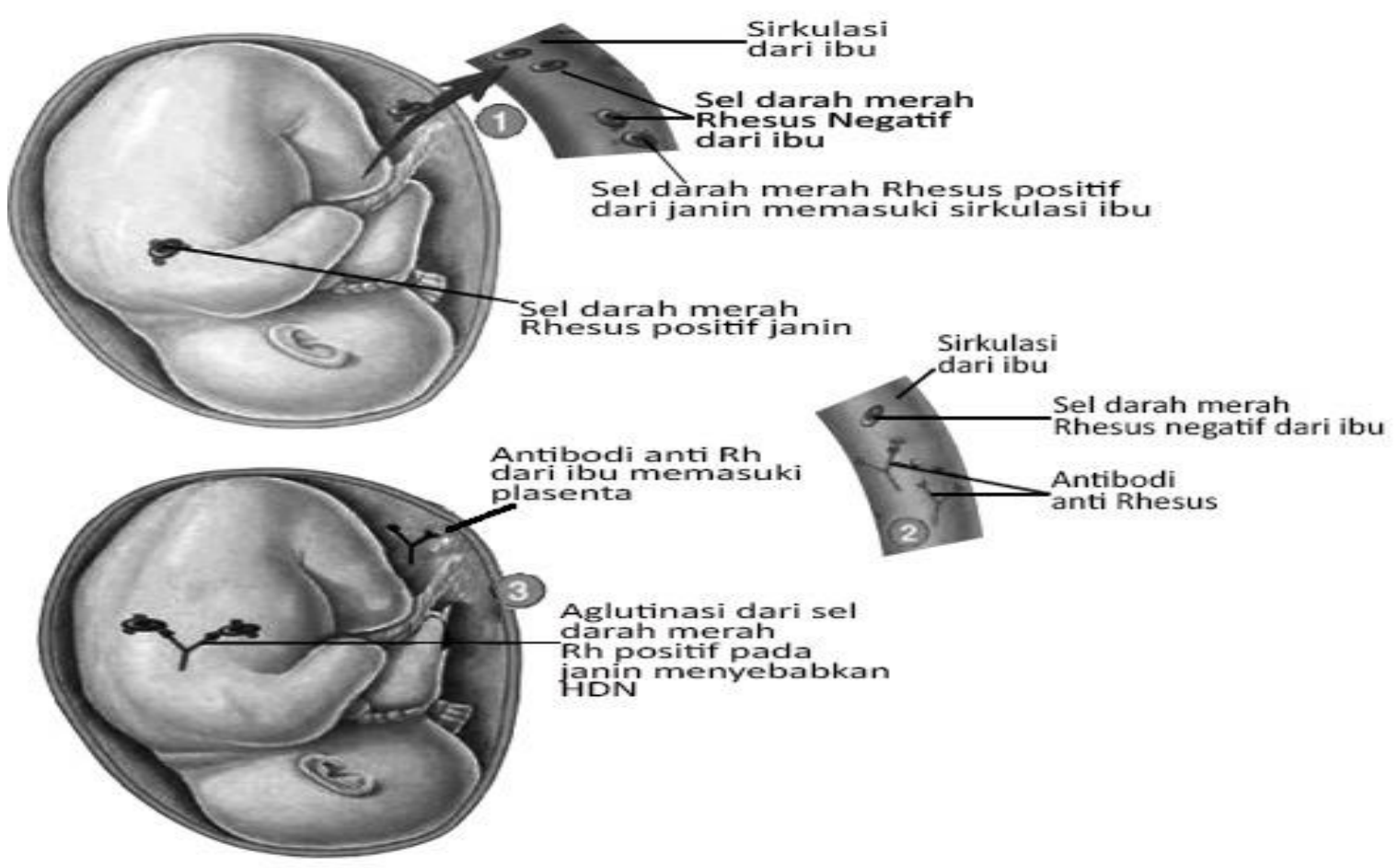

Gambar 1. Hemolytic Disease of the Newborn (HDN) Akibat Inkompatibilitas Rhesus ${ }^{8}$

Tidak seperti Inkompatibilitas Rh, anak pertama dapat mengalami HDN akibat inkompatibilitas $\mathrm{ABO}$ karena IgG anti-A dan anti $\mathrm{B}$ normal ada didalam golongan darah $\mathrm{O}$ dewasa sehingga eritrosit bayi menjadi target antigen diserang oleh 2 jenis antibodi. HDN akibat inkompatibilitas ABO biasanya tidak separah inkompatibilitas $\mathrm{Rh}$ karena eritrosit janin lebih mengekspresikan lebih sedikit antigen golongan darah ABO dibanding dewasa. Selain itu antigen golongan darah ABO diekspresikan dari berbagai jaringan sehingga sedikit kemungkinan berikatannya anti-A dan anti-B terhadap antigen target pada eritrosit bayi. Angka kejadian yang rendah pada HDN inkompatibilitas ABO juga dapat diakibatkan tipe antibodi pada anti-A dan anti- 
B sebagian besar adalah IgM yang tidak dapat melalui plasenta. ${ }^{3,4}$

Angka kejadian dan keparahan hiperbilirubinemia pada HDN akibat inkompatibilitas ABO dimungkinkan oleh adanya variasi promotor gen Uridin difosfat glukoniltransferase. Anemia berat disertai hidrops fetalis jarang ditemukan. ${ }^{4}$

Hemolytic Disease of the Newborn (HDN) akibat inkompatibilitas Kell umumnya dipicu oleh transfusi darah yang umum pada wanita ras Kaukasia. Patogenesis HDN akibat

Kell berbeda dengan rhesus dan tingkat keparahan lebih sulit diprediksi dibandingkan dengan inkompatibilitas rhesus. Ikatan eritrosit terhadap anti-K dianggap dapat menghambat aktivitas enzimatik glikoprotein Kell dan menekan hematopoiesis. Anti-K menghancurkan progenitor eritroid awal pada hepar bayi melalui proses imunologik. Dugaan ini timbul karena hemolisis pada inkompatibilitas Kell lebih sedikit, dan jarang ditemukan hiperbilirubinemia pasca kelahiran. ${ }^{4}$

\section{Gejala Klinik}

Gejala klinis gangguan hemolitik yang terjadi tergantung pada tingkat kepekaan respon imun. Anemia, ikterus, dan hepatosplenomegali pada bayi baru lahir adalah temuan utama pada penyakit hemolitik. Tingkat keparahan penyakit dapat berkisar dari hanya berupa hemolisis ringan (15\% kasus) hingga anemia berat dengan kompensasi hiperplasia jaringan eritropoesis yang menyebabkan pembesaran hati dan limpa yang masif. 7,9

Saat kapasitas kompensasi sistem hematopoesis terlampaui, maka anemia berat dapat terjadi (tampak pucat), tanda-tanda dekompensasi jantung (kardiomegali, gangguan pernapasan), edema anasarka, dan kolapsnya sistem sirkulasi. Gambaran klinis dari berlebihnya cairan abnormal pada 2 atau lebih kompartemen janin (pada kulit, pleura, perikardium, plasenta, peritoneum, cairan ketuban), disebut hidrops fetalis, sering menyebabkan kematian pada bayi dalam kandungan atau tak lama setelah lahir. ${ }^{8}$

Tingkat keparahan hidrops fetalis berkaitan dengan tingkat anemia dan tingkat penurunan serum albumin (tekanan onkotik), yang merupakan akibat dari disfungsi hati.
Hidrops fetalis dikaitkan dengan hematopoiesis ekstramedulla yang ditandai di hati, limpa, ginjal, dan kelenjar adrenalin, hipertensi portal dan pada vena umbilikalis, serta hipoproteinemia. ${ }^{7,8,9}$

Gagal jantung menyebabkan peningkatan tekanan jantung kanan sehingga menimbulkan edema dan asites. Kegagalan memulai pernapasan spontan dapat terjadi antara lain karena hipoplasi pulmonal, defisiensi surfaktan, edema paru atau efusi pleura bilateral. Hal ini dapat menyebabkan asfiksia hingga gangguan pernapasan berat. ${ }^{7,8,9}$

Petekie, purpura, dan trombositopenia juga dapat ditemukan pada kasus yang parah akibat penurunan produksi trombosit atau adanya bersamaan dengan diseminasi koagulasi intravaskular. ${ }^{8,9}$

Ikterus mungkin tidak timbul pada saat lahir, tetapi dapat muncul dalam beberapa hari atau beberapa jam setelah lahir jika terdapat hemolisis berat. Pada penyakit ringan, bilirubin akan memuncak pada hari ke 4 atau 5 setelah lahir dan menurun secara perlahan kemudian.Pada kasus yang berat, pigmen bilirubin akan menyebabkan cairan ketuban, tali pusat, dan verniks kaseosa akan berwarna kuning. Ikterus umumnya timbul pada hari pertama kehidupan bayi karena sistem konjugasi dan ekskresi bilirubin tidak dapat mengatasi beban yang dihasilkan dari adanya hemolisis yang masif. Bilirubin indirek yang terakumulasi dapat mencapai kadar yang tinggi dan menyebabkan ensefalopati. ${ }^{7,9}$

Ensefalopati bilirubin akut pada awalnya ditandai dengan bayi tampak lesu, bayi tidak mau menyusu, dan hipotonia. Jika tidak tertangani, maka dapat menjadi tangisan nyaring, demam, hipertonia, opisthotonus, dan pernafasan tidak teratur. Ensefalopati yang berat dapat menyebabkan defek neurologis (misalnya, serebral palsy koreoatetoid, gangguan pendengaran sensorineural, dll). ${ }^{7}$

Pada kasus yang lebih ringan, hemolisis berlanjut sampai sel darah merah yang tidak kompatibel atau sampai IgG yang bertanggung jawab terhadap respon imun menghilang(waktu paruh IgG adalah 3 minggu) ${ }^{7}$

\section{Pemeriksaan Laboratorium}

Tes Penyaring

Menggunakan sampel darah ibu maka dapat dilakukan : 
1. Uji Rossete: merupakan uji kualitatif sebagai bukti telah terjadi perdarahan transplasenta sel D-positif. Apabila sel Dpositif bayi menembus plasenta dan masuk ke sirkulasi ibu, maka sampel darah yang diambil dari ibu dengan D-negatif akan mengandung sel D-positif. Apabila ditambahkan reagen anti-D ke dalam spesimen darah akan tampak aglutinasi mikroskopik, dan ditambahkan sel-sel Dpositif untuk memperkuat pemeriksaan akan tampak sebagai rossete sel-sel aglutinasi secara mikroskopik. Jika uji rosette positif maka harus dilakukan konfirmasi dengan uji Kleihauer-Betke. ${ }^{1,4-6}$

2. Uji Kleihauer-Betke (KB): merupakan uji untuk mengevaluasi perdarahan transplasenta besar dan juga untuk menghitung dosis RhIg yang diperlukan. Prinsip tes adalah hemoglobin bayi lebih resisten terhadap $\mathrm{pH}$ asam daripada dewasa. Sampel darah ibu yang mengalami perdarahan transplasental akan terdapat sejumlah kecil sel janin, dimasukkan ke dalam larutan asam dan dibuat sediaan hapus yang diwarnai maka sel-sel janin akan tetap memperlihatkan pewarnaan hemoglobin sedangkan sel-sel dewasa akan tampak sebagai bayangan. Dilakukan penentuan persentase relatif sel terwarnai dan tidak terwarnai dan dikalikan dengan faktor koreksi untuk volume darah ibu. ${ }^{1,4,5}$

3. Flowsitometri: merupakan tes kuantitatif sel fetus pada sirkulasi maternal, dapat menggunakan antibodi anti-fetal hemoglobulin (anti $\mathrm{HbF}$ ), antibodi anti-D, kombinasi anti $\mathrm{HbF}$ dan antibodi anti $\mathrm{D}$, dan kombinasi anti $\mathrm{HbF}$ dan antibodi karbonik anhidrase. Flowsitometri menggunakan antibodi monoklonal terhadap $\mathrm{HbF}$ lebih baik dibandingkan dengan tes KB karena dapat membedakan secara akurat sel janin dan dewasa, secara cepat dan akurat menganalisis sel dalam jumlah besar, serta bersifat otomatik. Tes flowsitometri merupakan tes yang cocok digunakan sebagai tes konfirmasi adanya perdarahan transplasenta. ${ }^{1,4,5}$

4. Tes Antiglobulin Indirek (Coombs Test): merupakan tes penyaring untuk pencegahan terjadinya HDN dengan mendeteksi antibodi anti-D di dalam serum ibu sebelum menyerang eritrosit bayi. Pertama serum ibu diinkubasi dengan eritrosit yang Rh-D positif, bila ada anti-D dalam serum ibu maka akan berikatan. Sel-sel yang tidak berikatan akan dibuang saat pencucian. Ditambahkan anti-Ig kemudian, maka akan terjadi aglutinasi terhadap eritrosit

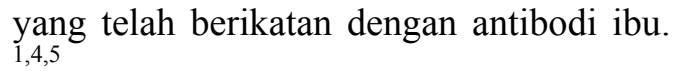

\section{Tes Diagnostik}

1. Pemeriksaan darah rutin dan pewarnaan darah tepi bayi. Kadar $\mathrm{Hb}$ yang rendah tergantung derajat keparahan hemolisis yang terjadi. Darah tepi menunjukkan banyak eritrosit polikrom, makrosit dan eritroblast, serta peningkatan jumlah retikulosit. Kadang ditemukan neutropenia dan trombositopenia. Pada Inkompatibilitas $\mathrm{ABO}$ lebih sering ditemukan sferositosis. ${ }^{4,8-10}$

2. Tes Antiglobulin Direk (Coombs Test): merupakan tes untuk mendiagnosis adanya HDN. Pertama eritrosit bayi dicuci untuk membuang semua antibodi yang tidak terikat. Ketika ditambahkan anti-Ig akan terjadi aglutinasi pada darah bayi yang sudah terikat dengan antibodi maternal. ${ }^{4,9}$

\section{Tes Follow Up Terapi}

1. Pemeriksaan kadar bilirubin. Kadar bilirubin indirek yang meningkat tergantung tingkat keparahan hemolisis, pada kemiketerus umumnya kadar bilirubin total menjadi lebih dari 20 $\mathrm{mg} / \mathrm{dL} .^{1,10,11}$

2. Pemeriksaan darah rutin, (terutama kadar hemoglobin dan hematokrit) untuk mengetahui adanya anemia lanjut dan pengawasan pasca transfusi. Pemeriksaan ini dapat dilakukan tiap 4-6 jam sekali. Interval pemeriksaan dapat menjadi semakin panjang seiring adanya perbaikan gejala dan hasil pemeriksaan. ${ }^{1,10,11}$

3. Pemeriksaan analisa gas darah. Pemeriksaan ini diperlukan karena pada bayi yang menjalani transfusi tukar cenderung mengalami asidosis dan hipoksia. ${ }^{1,10,11}$

4. Pemeriksaan kadar gula darah. Dapat tejadi penurunan kadar gula darah sebelum/pada saat transfusi atau setelah transfusi. ${ }^{1,10,11}$ 


\section{Diagnosis}

Diagnosis ditegakkan berdasarkan anamnesis, manifestasi klinis, pemeriksaan laboratorium dan pemeriksaan penunjang lainnya. Riwayat maternal, riwayat kehamilan, riwayat persalinan dan kesehatan ibu, pemeriksaan paternal secara lengkap perlu dianamnesis dengan baik untuk menegakkan diagnosis. ${ }^{8,9}$

\section{Diagnosis Banding ${ }^{7}$}

a. Isoimunisasi

b. Gangguan Enzim Eritrosit (Contoh: G6PD, Defisiensi Piruvat Kinase)

c. Gangguan sintesis eritrosis (Contoh: talasemia)

d. Abnormalitas membran eritrosit: sferositosis herediter, eliptosis

e. Hemangioma (Sindrom Kasabach Merrit)

f. Kondisi lain yang didapat seperti sepsis, infeksi TORCH, infeksi Parvovirus B19 (anemia aplastik), dan hemolisis sekunder akibat obat

\section{Pencegahan}

Pencegahan dimulai pada kunjungan prenatal pertama. Anamnesis yang cermat meliputi setiap masalah yang terkait dengan kehamilan atau persalinan sebelumnya, transfusi darah sebelumnya, atau kelainan darah. Pada awal pemeriksaan laboratorium harus mencakup pemeriksaan golongan darah $\mathrm{ABO}$, status $\mathrm{Rh} \mathrm{D}$ dan skrining antibodi. Untuk skrining antibodi, tes antiglobulin indirek menggunakan reagen sel darah merah yang tersuspensi dalam salin, karena reagen ini paling cocok untuk mendeteksi antibodi yang signifikan. Jika skrining antibodi Rh-D positif, maka tes antibodi dan titer antibodi harus diulang dan penentuan untuk memastikan apakah ada antibodi lain yang dapat menyebabkan penyakit hemolitik. ${ }^{12,13}$

Jika antibodi $\mathrm{Rh} \mathrm{D}$ positif, maka pasien harus ditanyai tentang injeksi imunoglobulin anti-D sebelumnya karena hal ini bisa menjadi penyebab titer antibodi positif. Imunoglobulin anti-D adalah imunoglobulin pasif yang bila diberikan kepada wanita negatif Rh-D akan mencegah sebagian besar kasus hemolitik. Setelah skrining awal pada kunjungan prenatal pertama, skrining antibodi Rh-D berikutnya dilakukan pada usia kehamilan 24 hingga 28 minggu. Jika skrining antibodi negatif, maka diberikan $300 \mu \mathrm{g}$ imunoglobulin anti-D dan sekali lagi dalam 72 jam setelah melahirkan jika neonatus positif Rh-D. ${ }^{12}$

Setelah pemberian profilaksis, anti D dapat dideteksi oleh tes antiglobulin indirek. Kekebalan anti D menjadi terdeteksi sekitar empat minggu setelah terpapar sel D positif dan mencapai puncaknya setelah enam hingga delapan minggu. Bila ibu sudah pernah tersensitisasi, tentukan apakah bayi beresiko dan lakukan pengawasan. Setelah terkonfirmasi adanya anti-D maternal maka tentukan golongan darah $\mathrm{Rh}$ bayi dengan mengambil sampel melalui cairan amnion atau tali pusat. ${ }^{12,13}$

\section{Penatalaksanaan Saat kehamilan :}

Setelah kehamilan diidentifikasi berisiko karena tes antiglobulin indirek positif atau meningkat, maka harus di lakukan USG Doppler MCA (middle cerebral arterial) secara serial untuk memantau adanya anemia pada janin. Jika terdeteksi anemia ringan, maka pemantauan dengan ultrasonografi secara serial harus tetap dilanjutkan sampai paru janin cukup matang atau cukup waktu kehamilan. ${ }^{7,8,11,15}$

Jika diduga anemia berat, maka dapat dilakukan kordosentesis untuk mengkonfirmasi hal tersebut (hematokrit < $30 \%$ atau hemoglobin $<10 \mathrm{~g} / \mathrm{dL}$ ). Jika terjadi anemia berat, maka transfusi intrauterin dapat mencegah bayi mengalami hidrops yang berat. Penurunan kadar hematokrit pada pasien hemolitik berat sangat cepat sehingga dibutuhkan transfusi kedua dalam waktu 7-14 hari setelahnya. Target transfusi adalah sampai hematokrit mencapai $40-45 \%{ }^{7,8,11}$

Transfusi darah yang digunakan haruslah sel darah merah yang segar, tidak mengandung sitomegalovirus, sedikit leukosit, dan diiradiasi untuk mencegah reaksi imun. Penggunaan darah antigen- Kell negatif akan lebih baik jika tersedia. ${ }^{7,8,14}$

Neonatus yang telah menerima transfusi intrauterin berulang untuk pengobatan hemolisis dapat mengalami perubahan dalam dirinya. Efek transfusi intrauterin salah satunya pada hemoglobin janin, hemoglobin menjadi berumur pendek karena adanya residu sel darah merah janin 
yang dilapisi antibodi. Hemopesis janin biasanya tertekan sehingga bayi yang baru lahir yang menerima transfusi hingga dekat masa kelahiran mengalami ikterus neonatal ringan, yang mungkin tidak memerlukan fototerapi dan tidak ada anemia neonatal. $^{7,8,11,15}$

Pada beberapa kasus yang tidak memungkinkan dilakukannya transfusi intra uterin, maka pemberian imunoglobulin intravena (IGIV) pada ibu telah diusulkan sebagai terapi alternatif sampai transfusi intravaskular dimungkinkan. Mekanisme kerja berupa penghambatan umpan balik dari sintesis antibodi ibu, blokade reseptor retikuloendotelial, atau blokade transpor antibodi plasenta. Pemberian IGIV dapat mengurangi hemolisis sekunder sehingga mengurangi kebutuhan untuk transfusi tukar, lebih efektif dan non invasif dibandingkan dengan transfusi tukar. Kombinasi plasmapheresis dan pemberian IGIV telah dilaporkan berhasil dalam pengobatan, meskipun biaya pengobatannya tinggi. ${ }^{7,8,12}$

\section{Pasca Kelahiran}

Bayi yang terkena HDN harus diamati secara intensif dengan pemantauan laboratorium hemoglobin dan bilirubin untuk menentukan apakah fototerapi, transfusi tukar atau pemberian imunoglobulin intravena (IGIV) diperlukan. Meskipun transfusi tukar adalah terapi kritis untuk pencegahan kernikterus pada bayi dengan bilirubin tinggi, tapi hal ini memiliki komplikasi tersendiri. Pemberian IGIV telah terbukti mengurangi kebutuhan untuk transfusi pertukaran dalam beberapa penelitian. ${ }^{8,16,17}$

Anemia pada bayi dapat menetap tergantung waktu paruh oleh antibodi yang berada dalam tubuh. Anemia juga dapat menetap akibat adanya penekanan eritropoiesis. Antibodi yang diturunkan oleh ibu pada bayi yang menjalani transfusi intrauterin atau transfusi tukar dapat bertahan lebih lama dari yang diperkirakan, karena kurangnya sel darah merah antigen positif untuk mengikat antibodi. Jika bayi tidak mau menyusu dan cenderung tidur, maka hal ini bisa menjadi tanda anemia hipoproliferatif yang menetap. Pemeriksaan hematokrit dan retikulosit juga harus dilakukan secara teratur untuk memantau adanya pemulihan sumsum tulang atau kebutuhan transfusi sel darah merah. $8,16,18$

Setelah dilahirkan, bayi dapat mengalami hiperbilirubinemia akibat peningkatan bilirubin tak terkonjugasi. Fototerapi dengan panjang gelombang 460 hingga $490 \mathrm{~nm}$ digunakan untuk mengubah bilirubin tak terkonjugasi menjadi isomer, yang lebih sedikit lipofilik dan kurang toksik bagi otak dan dapat dikeluarkan tanpa melalui konjugasi hepatik. Fototerapi perlu segera dilakukan pada pasien dengan hemolisis sedang atau berat atau dengan peningkatan bilirubin yang cepet $(>0,5 \mathrm{mg} / \mathrm{dL} / \mathrm{jam}) .8,16,19$

Dosis yang relatif tinggi diberikan dengan menggunakan dua tepi lampu untuk mengelilingi tubuh bayi. Pada bayi dengan hemolisis ringan hingga sedang atau riwayat transfusi intrauterin, fototerapi umumnya cukup. $^{8,16}$

Immunoglobulin intravena (IGIV) semakin sering digunakan mengobati hiperbilirubinemia pada bayi baru lahir yang mengalami HDN. IGIV bersaing dengan antibodi ibu pada reseptor makrofag di limpa bayi untuk mengurangi jumlah hemolisis. ${ }^{8,16}$

Transfusi tukar adalah penggunaan darah lengkap untuk menggantikan darah dalam sirkulasi bayi. Transfusi tukar dilakukan dalam waktu 9-12 jam setelah lahir. Transfusi tukar harus segera dilakukan pada bayi bila ditemukan tanda-tanda ensefalopati bilirubin walaupun dalam pemeriksaan kadar bilirubinnya turun. ${ }^{8,16,17}$

Transfusi tukar digunakan terutama untuk menghilangkan bilirubin tak terkonjugasi yang tinggi dan untuk mencegah kernikterus. Bayi prematur lebih mungkin memerlukan transfusi tukar dibandingkan bayi aterm karena fungsi hati yang belum sempurna sehingga kurang mampu untuk mengkonjugasikan bilirubin. Keuntungan lain dari transfusi tukar adalah untuk membersihkan sirkulasi bayi dari antibodi ibu yang bersirkulasi, sel darah merah yang tersensitisasi, dan penggantian sel darah merah yang tidak kompatibel dengan sel darah merah yang kompatibel. Pemeriksaan yang diperlukan setelah transfusi dilakukan antara lain pemeriksaan hemoglobin, hematokrit, morfologi sel darah, kadar bilirubin total atau indirek dan retikulosit. ${ }^{8,17-19}$ Terapi farmakologi dapat mempertimbangkan pemberian phenobarbital intravena. ${ }^{20}$ 


\section{Prognosis}

Penurunan mortalitas pada HDN terjadi sejak adanya perkembangan penanganan. Kemampuan bertahan hidup pasien HDN akibat inkompatibilitas $\mathrm{Rh}$ tanpa edema meningkat $90 \%$ dengan pemberian transfusi intrauterina, namun bila ada hidrop fetalis maka kemampuan bertahan hidup pasien hanya sekitar $26 \%$. Bayi prematur dan berat badan lahir rendah cenderung rentan terhadap kerusakan otak akibat hiperbilirubinemia. ${ }^{7}$

Tabel 1. Perbandingan antara Inkompabilitas Rhesus dan $\mathrm{ABO}^{8}$

\begin{tabular}{lcc}
\hline \multicolumn{1}{c}{ Karakteristik } & Rhesus & ABO \\
Golongan darah & & O \\
\hline Ibu & Negatif & A atau B \\
Janin & Positif & IgG2 \\
Tipe antibodi & IgG1 dan/atau IgG3 & \\
Aspek Klinis & & \\
Angka Kejadian pada Anak & $5 \%$ & \\
Pertama & & Jarang \\
Prediksi Tingkat keparahan & Umum & \\
pada kehamilan berikut & & Jarang \\
Abortus dan/atau Hidrops & Sering & Jarang \\
Anemia berat & Sering & + \\
Derajat Ikterus & +++ & + \\
Hepatosplenomegali & +++ & \\
Pemeriksan Lab & & Belum jelas \\
Antibodi Maternal & Selalu ada & + \\
DAT (janin) & + & + \\
Sferosit & - & Tidak \\
Penatalaksanaan & & Jarang \\
Pemeriksaan antenatal & Ya & Gol.darah O \\
Transfusi tukar & Sering & Jarang \\
Tipe donor & Sering & \\
Kejadian Anemia laten & & \\
& &
\end{tabular}

\section{Penutup}

Hemolytic Disease of the Newborn (HDN) merupakan sindrom anemia hemolitik yang terjadi akibat proses imun yang timbul saat antibodi dari sirkulasi ibu yang berikatan dengan eritrosit bayi dan dihancurkan karena ketidakcocokan/inkompabilitas golongan darah baik Rhesus, ABO maupun golongan darah lainnya. Inkompatibilitas $\mathrm{Rh}$ terjadi pada ibu Rh-negatif dan anak Rh-positif dan umumnya bukan pada anak pertama. Inkompatibilitas $\mathrm{ABO}$ terjadi pada ibu bergolongan darah 0 dan anak $\mathrm{A}$ atau $\mathrm{B}$, dengan tingkat keparahan lebih ringan dibandingkan $\mathrm{Rh}$ pada umumnya. Inkompatibilitas golongan darah lain jarang, namun yang lebih sering adalah golongan darah Kell (Tabel 1).

Diagnosis ditegakkan berdasarkan anamnesis termasuk riwayat kehamilan ibu, gejala klinik, pemeriksaan laboratorium dan pemeriksaan penunjang lain. Gejala klinik yang ditemukan adalah pucat akibat anemia, ikterus, edema, gangguan pernapasan, hepatosplenomegali dan purpura.

Pemeriksaan laboratorium yang dapat dilakukan adalah uji rossete. Uji KleihauerBetke, Direct and Indirect Coombs Test, pemeriksaan darah rutin dan darah tepi, serta pemeriksaan kadar bilirubin. Penatalaksanaan yang dapat diberikan adalah transfusi intrauterin, transfusi tukar, fototerapi dan pemberian imunoglobulin IV dosis tinggi. Prognosis kemampuan hidup pasien meningkat bila ditangani dengan baik, namun rendah bila pasien sudah mengalami hidrops fetalis. 


\section{Daftar Pustaka}

1. Sacher, Ronald A. Tinjauan klinis pemeriksaan laboratorium. 2009. EGC : Jakarta. Hal 271-76.

2. Kumar A, Patel MK, Chavda B, Ranjan A, Ahmad F. Hemolytic disease of the newborn: a study of 50 cases. International Journal of Scientific Study, 2013; 01:13.

3. Dean L. Hemolytic disease of the newborn. blood groups and red cell antigens chapter 4. National Center for Biotechnology Information (US); 2005.

4. Porwits A, McCullough J, Erber W. Blood and bone marrow pathology $2^{\text {nd }}$ Ed. Toronto: Churchill Livingstone; 2011; p. 599-05.

5. Kim YA, Makar RS. Detection of fetomaternal hemorrhage. American Journal of Hematology, 2012; 87: 417423.

6. Krywko DM, Shunkwiler SM. Kleihauer Betke test. [Updated 2019 Jan 27]. In: StatPearls [Internet]. Treasure Island (FL): StatPearls Publishing; 2019 March 7.

7. Lanzkowsky P. Manual of Pediatric hematology and oncology. $6^{\text {th }}$ Ed. California: Elsevier Academic Press; 2016; p. 51-68.

8. Lichtman M, Beutler E, Selighson U, Kaushansky K, Kipss T, et al. Williams Hematology. $9^{\text {th }}$ Ed Chapter 25. California: Mc Graw-Hills Medical; 2015.

9. Gielezynska A, Stachurska A, FabijanskaMitek J, Debska M, Muzyka K, Kraszewska E. Quantitative fetomaternal hemorrhage assessment with the use of five laboratory tests. International Journal of Laboratory Hematology, 2016;38(4):419-25.

10. Watchko JF. Common hematologic problems in the newborn nursery. Pediatrics Clinic of North America, 2015;62: 509-24.

11. Kliegman RM, Behrman RE, Jensen HB, Stanton B. Nellson Textbook of pediatrics. $20^{\text {th }}$ Ed.Chapter 103. New York: Elsevier Publisher; 2016.

12. Martin JR, Fanaroff AA, Walsh CM. Fanaroff and Martin's neonatal-perinatal medicine. $10^{\text {th }}$ Ed Chapter 24. Philadelphia: Elsevier Saunders; 2015; p.327-34.

13. Basu S, Kaur R, Kaur G. Hemolytic disease of the fetus and newborn: current trends and perspectives. Asian Journal Transfusion Science, 2011;5:3-7.

14. Murray NA, Roberts IAG. Haemolytic disease of the newborn. Arch Dis Child Fetal Neonatal Ed. 2007; 92: F83-F88.

15. Ross ME, Waldron PE, Cashore WL, de Alarcon PA. Hemolytic disease of the fetus and newborn. In: de Alarcon PA, Werner EJ, Christensen RD editors. Neonatal hematology. 2nd ed. Cambridge UK: Cambridge University Press; 2013. p. 65-90.

16. Miqdad AM, Abdelbasit OB, Shaheed M, Seidahmed AM, Abomelha AM, et al. Intravenous immunoglobulin G (IVIG) therapy for significant hyperbilirubinemia in $\mathrm{ABO}$ hemolytic disease of the newborn. The Journal of Maternal-Fetal and Neonatal Medicine, 2004;16:163-6.

17. Delaney M, Matthews DC. Hemolytic disease of the fetus and newborn: managing the mother, fetus, and newborn. Hematology Am Soc Hematol Educ Program. 2015; (1):146-5.

18. Kennedy MS, Krugh D. Hemolytic disease of the newborn and fetus. In: Harmening DM, editor. Modern blood banking and transfusion practices. 5th ed. Philadelphia : FA Davis Company; 2008. pp. 385-95.

19. Roberts IA. The changing face of haemolytic disease of the newborn. Early Human Development, 2008;84:515-23.

20. Ullah S, Rahman K, Hedayati M. Hyperbilirubinemia in neonates: types, causes, clinical examinations, preventive measures and treatments: a narrative review article. Iran Journal Public Health, 2016; 